\title{
ON SOME SELECTED PROBLEMS OF KOREAN ABBREVIOLOGY
}

\author{
Anna BOROWIAK \\ Adam Mickiewicz University \\ Institute of Linguistics, Department of Korean Studies \\ Al. Niepodległości 4, Poznań, Poland \\ annaboro@amu.edu.pl
}

\begin{abstract}
Given the fact that we live in the era where the pace of life is constantly speeding up, it is no surprise that 'the economy of language' - meaning the efficient usage of language in order to achieve the maximum effect for the minimum effort has become so important in everyday life. Using abbreviated forms of different kinds is supposed to help us to economize continuously insufficient amount of time. Their overuse, however, can hamper effective communication and bring the adverse effect from what the speaker's intention was - namely to communicate the message clearly and unambiguously and receive a response to it in a short time. Incomprehension or misunderstanding of the message leads, in fact, to unnecessarily prolonging the conversation since it requires asking additional questions in order to explain what is unclear to the listener.

Reduced forms used mainly in spoken Korean can largely be divided into lexical and grammatical ones. Lexical shortenings of different kinds such as acronyms, blends, clippings etc. although rarely and rather briefly discussed by Korean linguists and basically excluded from the debate on word-formation issues definitely deserve much more attention taking into account their extensive usage. As for grammatical abbreviations, despite its frequent occurrence, the subject is not that often taken up and discussed either.

The aim of this article is to present some characteristic properties of grammatical abbreviations used mainly in spoken Korean. The reduced forms in question will be divided into three categories namely - particles, endings and grammatical constructions and discussed separately. This article however focuses only on those abbreviated forms, which means leaving the subject of particle or word ellipsis beyond its scope.
\end{abstract}


Key words: Korean, abbreviated forms, grammatical abbreviation, clippings, contractions

\section{한국어 축약형에 관한 고찰}

논문초록: 우리는 생활의 속도가 지속적으로 가속화되어 가고 있는 시대에서 살고 있다. 이러한 사실을 감안해 볼 때 최소의 노력으로 최대의 효과를 얻을 수 있다는 목적을 달성하기 위한 '언어의 경제성'이 일상생활에서 그만큼 중요해졌다는 것은 놀랄 만한 일이 아니다. 다양한 종류의 '줄어든 말 (축약)'의 사용은 충분하지 않은 시간을 절약할 수 있도록 우리에게 도움을 준다. 그런데 '줄어든 말'의 남용은 원활한 의사소통을 방해할 수 있으며, 결국에는 분명하고 명확하게 정보를 전달하고 짧은 시간 안에 청자의 응답을 받으려는 화자의 의지와는 전혀 다른 반응, 즉 역효과를 가져올 수도 있다. 실제로 화자가 말한 내용을 청자가 이해하지 못하거나, 잘못 이해한 경우에는 불필요한 담화를 지속해야 할 수도 있다. 왜냐하면 명확하지 못한 부분을 설명하기 위한 추가 질문과 대답이 필요하기 때문이다.

대체로 구어체 한국어에서 사용되는 축약형은 크게 어휘 단위가 축약된 '준말'과 문법적인 단위의 음운 탈락이나 축약인 '줄어든 말'로 나눌 수 있다. 두문자어 (acronyms), 혼성어 (blends), 단축어 (clipping) 등과 같은 축소된 어휘 단위가 한국 언어학자들에 의하여 간략하게 언급되며 기본적으로 어휘형성법에 관한 논의에서 제외되어 있으나, 일상생활에서 그러한 어휘의 광범위한 사용을 고려한다면 훨씬 더 많은 연구의 대상이 되어야 한다. 그리고 문법 단위가 축약된 형태 또한 빈번하게 사용됨에도 불구하고 연구의 대상이 되는 경우는 흔하지 않다.

본 연구는 주로 구어체 한국어에서 사용되는 축약된 문법 단위를 관찰하여 그 특질을 드러내는 데에 목적이 있다. 본 연구는 조사와 어미, 문법적 구조의 세 가지 범주를 대상으로 하위 구분하여 논의할 것이다. 그러나 이 연구는 축약된 문법 단위만을 논의 주제로 삼되 조사나 어휘의 탈락은 논외로 한다.

핵심어: 한국어, 축소어형, 문법적인 축소, 단축어, 축약 


\section{List of Abbreviations}

The following abbreviations are used to label word classes and their grammatical properties:

$1 \mathrm{SG}, 2 \mathrm{SG}, 3 \mathrm{SG}-1^{\text {st }}, 2^{\text {nd }}, 3^{\text {rd }}$ person singular

1PL, 2PL, 3PL $-1^{\text {st }}, 2^{\text {nd }}, 3^{\text {rd }}$ person plural

ACC - accusative

ADJ-adjective

AST - adjective stem

AUX - auxiliary

$\mathrm{c}-$ consonant

DEM $\mathrm{P}$ - demonstrative pronoun

END - ending

GEN - genitive

HUM - humble form

IND $\mathrm{P}$ - indefinite pronoun

LOC - locative

$\mathrm{N}$ - noun

NEG - negative

NEU - neutral form

NOM - nominative

$\mathrm{P}$ - pronoun

$\mathrm{PP}$ - personal pronoun

PART - particle

PRED - predicative

PRES - present

PST - past

POSS - possessive

TC PART- topic-contrast particle

V- vowel

$\mathrm{V}$ - verb

VST- verb stem 


\section{Introductory Remarks}

Abbreviating of various linguistic units such as lexemes, phrases, etc. is nothing new. As Szadyko (1997: 116) and Podracki (1999: 11) explain the tendency to economize in expression is presumably as old as handwriting itself, since it was already known and frequently used in Roman and Medieval Times. Buttler (1987: 641) considers it to be one of the age-old and evolutionary tendencies of a language system. Szadyko (1997: 116, 120) not only argues that it corresponds, to some extent, with the developmental tendencies of contemporary languages but also convinces that it is one of the most productive ways of enriching the lexicon of the written form of technical language, especially the language of business. Bauer (1994: 83) notices on the example of changes in the Standard English in the 20th century the increase in the number of blends and 'abbreviations' with the decrease in the number of words derived through suffixation.

Nevertheless despite its growing productiveness over the past few decades shortening of lexical material as Hamans (2008: 95-98) points out is scarcely documented and hardly discussed in modern linguistic theory, since it is considered to be an irregular and relatively rare process. He, however, notices in this phenomenon of modern languages some certain regularity. Bauer (2001) refers to those nonstandard processes of word-formation, by which he means clipping, blending and acronyming, as 'non-rule governed innovations'. Marchand (1966: 364) explains that even though the shortening of a syntactical group generally called ellipsis is old, he presumes that the phenomenon of word clipping as we understand it today, was unknown in Ancient Times and that in English it does not seem to be older than 15 th $\mathrm{c}$.

The subject of abbreviation in Korean is also rarely discussed in comparison to other various aspects concerning the field of wordformation. Neither 최현배 (1994) nor 시정곤 (1994), 김정은 (2000), 남기심 and 고영근 (2006), 나찬연 (2007) and others make no mention about them at all. Although some authors such as 김창섭 (1996) do mention curtailed forms but their whole description comes down to just one paragraph. The author who despite a brief description intro- 
duces their classification is 최규일 (2007: 32, 265). He lists them along with compounding, derivation and inflection, among four ways of forming new words through morphological process. He treats them, however, as a special form of word-formation by using the term teuksu bangbeop (Kor. 특수 방법) and divides them into 4 categories - namely blending or contamination (Kor. 혼성법, honseongbeop), shortening (Kor. 단축법, danchukbeop), clipping (Kor. 절취법, jeolchwibeop) and acronymy (Kor. 두문자 약자 사용, dumunja yakja sayong), nevertheless offers no examples. He also mentions shortenings apropos the language being used in the Internet (cf. pp. 232-233), which is described there as 'a place where new words are being created beyond the rules of basic rules of orthography or the grammar of the language'. 이지양 (1993), as one of the few linguists investigates the question of fusion (Kor. 융합, yonghap) and its forms in Korean defining the necessary conditions in order for fusion to take place. $\mathrm{He}$ also divides fusion into two categories on the basis of changes and refers to few features of fused forms pointing out that they have not been given much attention since they lack regularity.

On the basis of books both written and published in South Korea we can presume that the subject of abbreviation or contraction is rather a new field closely connected with constantly growing pressure of time, technological and social changes, unfortunately not always positive ones, ${ }^{32}$ which have happened within the past several years. This would explain why finding in-depth analysis of this subject is quite difficult.

Interestingly enough in books printed outside of Korea, the subject is given somewhat more attention. Those books however, as the above-mentioned ones, address only the question of lexical units. Lee and Ramsey (2011) for example refer to abbreviations in the Contemporary Korean as to vocabulary trends; Song (2005: 91) describes abbreviation as 'a minor but productive manner of word formation in Korean'. Long phrases, as he explains, are abbreviated and after a period of co-existence, abbreviated forms may take over from their source phrases. Choo and Kwak (2008: 115-6) give several examples of contractions (mainly nouns and phrases) and divide them into 4

\footnotetext{
${ }^{32}$ Cf. 'the mental reasons' for using shortenings indicated by 려춘연 (1999: 35), to which he includes, among others, sheer laziness.
} 
groups, namely where the dropping of either the first or the last part of the word or phrase takes place, the group of compounds or phrases in which usually the first of each element is being omitted and the last group consists of loan words. Sohn (1999: 259-61) indicates, despite a brief description, that abbreviations are observed most extensively in SK compounds, especially in non-human proper nouns but admits that it can also occur 'quite extensively' in loan words and that the abbreviations of native words are rather sporadic.

Despite the fact that curtailed forms not only are known for a very long time but also frequently used, abbreviology as a discipline of linguistics is a relatively young field. Müldner-Nieckowski (2007: 8) uses this term in the preface to his dictionary and defines it as 'a science on language abbreviations'. ${ }^{33}$

Even though short forms on the basis of their properties can be divided into lexical and grammatical ones, if they are the subjects of discussion whatsoever, lexical abbreviations are usually the ones referred to. According to Cambrigde Online Dictionary lexical abbreviations can be divided into:

$$
\text { acronyms }^{34}
$$

(iii) clippings $^{36}$

However apart from the lexical abbreviation there is also grammatical one, which applies to grammatical units, as mentioned above. The resultant forms in Korean, as this article will attempt to show, are formed through the reduction of:

(i) particles,

(ii) endings and

(iii) grammatical constructions.

\footnotetext{
${ }^{33}$ Majewska-Wójcik et al. (2013: 201) consider the date of publishing this dictionary as a beginning of this field of linguistics in Poland.

${ }^{34}$ For the discussion on acronyms, their history and classification refer to Cannon (2011: 99-127).

${ }^{35}$ For the discussion on blends and their classification on the basis of etymological transparency cf. Bauer (1983: 234-36).

${ }^{36}$ For the discussion and classification of clippings see Marchand (1966: 357-61).
} 
The aim of this paper is to analyze the reduced forms used mainly in spoken Korean, which are the outcome of grammatical abbreviation. Talking about shortening of phrases or syntactical units the term contraction is the most convenient to be used. However contraction, as this article will try to show, is not the only process that takes place while abbreviating grammatical units in Korean since there is also clipping involved.

\section{Particles $^{37}$}

As far as shortening of particles is concerned it can be done either through contraction or clipping. Contraction generally takes place in two cases - namely when a particle is attached to an indeclinable word in Korean such as noun, pronoun etc., to another particle following those word classes or when it is attached to an ending of conjugated forms of verbs or adjectives. Among clipped forms of particles both back and fore clippings can be found.

\subsection{An indeclinable word form with a particle}

Particles in Korean can be divided according to their meaning and function into three major categories - namely grammatical case particles (Kor. 격조사, gyeokjosa), conjunction particles (Kor. 접속조사, jeopsokjosa) and auxiliary particles also known as semantic or even 'special' particles (Kor. 보조사, bojosa) (cf. 나찬연 2007: 154,

\footnotetext{
${ }^{37}$ Although the term particle is used by Martin (1992), Lee et al. (2000), Sohn (2001), Song (2005), Choo et al. (2008) and others, some scholars such as Rhee (2006), Ko (2008) prefer to use the term postposition, or some as 황경수(2009) postpositional word. In this article however only the term particle will be used.
} 
박동호 2005: 178, Lee et al. 2000: 139, 임지룡 et al. 2005: 163). Nevertheless some Korean scholars such as 최현배 (1994: 611-13), 남기심 and 고영근 (2006: 99) as well as others distinguish only two groups - namely case and auxiliary particles, which means including the above-mentioned second group into case particles. ${ }^{38}$

However, regardless of the differences in classification of particles in Korean, it appears that the process of abbreviation although very common applies mainly to the most frequently used ones.

As far as the case particles are concerned only particles such as the nominal case particle (Kor. 주격조사, jugyeokjosa), the accusative case particle (Kor. 목적격조사, mokjeokgyeokjosa), the genitive case particle (Kor. 관형격조사, gwanhyeonggyeokjosa), some of the adverbial case particles (Kor. 부사격조사, busagyeokjosa) are actually shortened. Examples are given below.

Ex. 1. Nominal case particle
a) 이것
igeot $+\quad \begin{aligned} & - \text { 이 } \\ & -i\end{aligned} \rightarrow$ $\begin{array}{ll}\text { 이것이 } \rightarrow & \text { 이게 } \\ \text { igeosi } & \text { ige }\end{array}$ 'this (thing)' this: DEMP NOM PART
b) 저것 $+\quad-$ 이 $\rightarrow$ 저것이 $\rightarrow$ 저게 'that(thing)'

38 남기심 and 고영근 (2006: 99) distinguish 7 cases in Korean - the nominal case (주격), the predicative case (서술격), the accusative case (목적격), the complement case (보격), the genitive case (관형격), the adverbial case (부사격) and the vocative case (호격). 임호빈 (1997: 102) however, mentions only six of them excluding the predicative case form his list, which is a confirmation of a disagreement concerning this particular case among Korean scholars. According to Traditional Grammar particles such as $-e$ (-에) 'to (a place)', -eseo (-에서) 'from/ in (a place)', -ege (-에 게), hante (-한테) 'to/ for (somebody)', -boda (-보다) 'more than somebody/ something' and others are considered 'adverbial case particles' since they enable a noun or a pronoun to become an adverbial in a sentence. They can however be subdivided into the locative case (처소격), the instrumental case (도구격) etc. (cf. 임지룡 et al. 2005: $164-5,493)$. 김원경 (2009) divides cases in Korean language into morphological and semantic ones and discusses their properties. Among morphological ones he lists: the nominal case (주격), which he calls the subject case, the accusative case (목적격) which he calls the object case, the genitive case (속격) and the adverbial case (부사격). Among semantic cases he lists: the experiencer case (경험자격), the agent case (행위자격), the beneficiary case (수혜자격), the theme case (객체격), the source case (원천격), the goal case (도달격), the path case (경로격), the locative case (처소격), the possessive case (소유격), the complement case (보어격) etc. 


jeogeot $-i$ jeogeosi jeoge
that:DEMP NOMPART

Ex. 2. 이게 뭐야? 'What's this?' (informal style)

Ige mwoya?

Ex. 3. Accusative case particle

a) 회사 + -를 $\rightarrow$ 회사를 $\rightarrow$ 회살 $\begin{array}{ccc}\text { hoesa } & - \text { reul hoeaseul hoesal } \\ \text { company: } \mathrm{N} & \text { ACCPART }\end{array}$

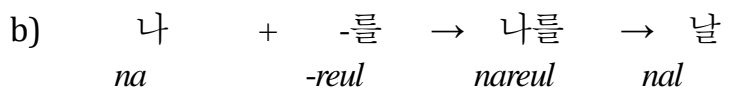
I/me: 1SGNEU PP ACCPART

c) 누구 + -를 $\rightarrow$ 누구를 $\rightarrow$ 누굴

$$
\begin{array}{lll}
\text { nugu } & - \text { reul nugureul nugl } \\
\text { who: INDP } & \text { ACC PART } &
\end{array}
$$

Ex. 4. 아버지가 날 부르셨어요. '(My) father called me.' Aboji-ga nal bureusyeosseoyo.

Ex. 5. Genitive case particle
a) 나 ${ }_{n a}+\underset{-u i}{\rightarrow}$ 나의 $\underset{n a u i}{\rightarrow}$ 내 $\underset{n a e}{\rightarrow}$ 'mine'
I/me: 1SGNEU PP GEN PART

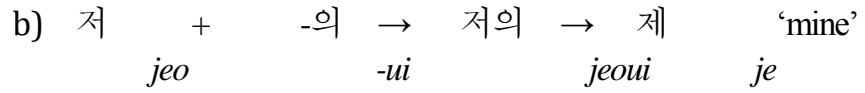

I/ me: 1SG HUM PP GENPART

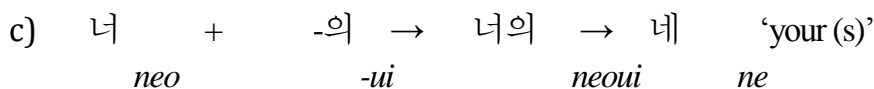
I/me: 2SG PP GENPART

Ex. 6. 이게 내 책이에요. 'This is my book.'

Ige nae chaegieyo. 
Ex. 7. Locative case particle

a)

$$
\begin{gathered}
\text { 나 } \\
n a
\end{gathered} \text { - }- \text {-에게 } \underset{\text { naege }}{\rightarrow} \text { 나에게 } \rightarrow \text { nege 내게 'to/ for/at me' }
$$

I/me: 1SG NEU PP LOC PART

b) 저 $\quad+\quad$ - 에게 $\rightarrow$ 저에게 $\rightarrow$ 제게 'to/ for/at me'

$$
\begin{array}{clll}
\text { jeo } & \text {-ege } & \text { jeoege jege } \\
\mathrm{V} / \mathrm{me} \text { 1SGHUMPP } & \text { LOCPART } &
\end{array}
$$

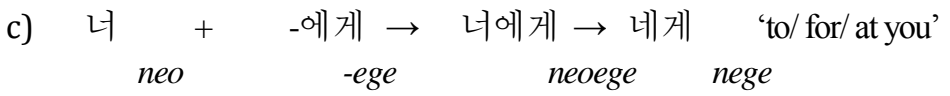

I/me: 2SG PP LOC PART

Ex. 8. 친구가 내게 선물을 줬어요. 'A friend gave me a present.'

Chinguga naege seonmureul jwosseoyo.

Examples just cited show that case particle can be shortened when attached to words which end in a vowel (with the exception of ex. 1-2). This means that the abbreviation is more frequent in consonant-ending words. Nevertheless, apart from morphological constraints regarding shortening of those particles there are also semantic ones involved. Since they concern mainly either nominal or demonstrative pronouns only.

The nominal case particle can be abbreviated only when attached to demonstrative pronouns igeot, geugeot and jeogeot (이것, 그것, 저것), which mean 'this/ these' (thing (s) ), 'the/ that/ those' (thing (s) ), 'that/ those (thing (s))' respectively. As the shortened forms show the reduction concerns both the last syllable of the pronoun and a particle itself. The same type of syllable restructuring applies to both the genitive case particle and the locative case particle meaning 'to/ for/ at somebody' although they are attached to 1SG and 2SG personal pronouns.

As a consequence of abbreviation, the accusative case particle -reul (-를) is reduced to $-r(-2)$. This reduction leads to restructuring of the last syllable of the preceding word too; it however does not have any part missing. $-r$ simply fills up the place of a consonant often referred to as batchim (받침). Among abbreviated forms with this particular particle, apart from 1SG and 2SG personal pronouns there are common nouns and indefinite pronouns as well.

Even though dangsin (당신), meaning 'you' is the 2SG pronoun, it is not abbreviated when attached to each of the above-mentioned particles. The 
reason could be its morphological structure - as mentioned above.

The vocative case particle (Kor. 호격조사, hogyeokjosa) such as - $a$ and $-y a$ (-아/야) and the complement case particle (Kor. 보격조사, bogyeokjosa) such as $-i$ and $-g a$ (-이/가), which are identical with the nominal case particles, are not shortened.

The most commonly abbreviated auxiliary particle, which is at the same time the most commonly abbreviated particle among all particles, is definitely-neun (-는). As this allomorph may suggest abbreviation of this so-called topic-contrast particle only takes place when a word ends with a vowel, as it is in the case of -reul (-를) discussed above. Here also, as a consequence of shortening the particle, it is reduced to a single phone, which is $-n$ (ᄂ) in this case. Few examples are given below.

Ex. 9.

a) 나 $+\underset{n a}{-} \underset{\text {-neun }}{\rightarrow} \underset{\text { naneun }}{\rightarrow \text { 나는 }} \rightarrow$ 난 $\mathrm{T}$ '

I: 1SG NEU PP TC PART

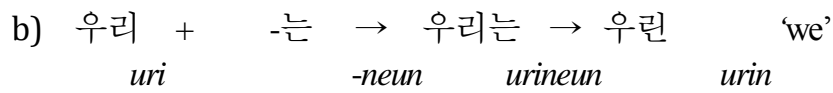

I: 1PLNEU PP TCPART

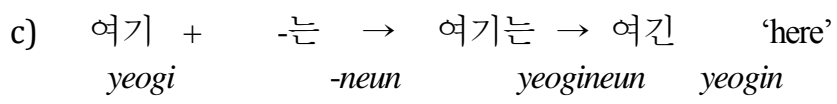

here: DEMP TCPART

d) 아버지 + -는 $\rightarrow$ 아버지는 $\rightarrow$ 아버진 'the father' abeoji -neun abeojineun abeojin father: N TC PART

e) 학교 + -는 $\rightarrow$ 학교는 $\rightarrow$ 학곤 'the school' $\begin{array}{lccc}\text { hakgyo } & \text {-neun } & \text { hakgyoneun hakgyon } \\ \text { school: } \mathrm{N} & \text { TCPART } & \end{array}$

f) 때로 + -는 $\rightarrow$ 때로는 $\rightarrow$ 때론

ttaero -neun ttaeroneun ttaeron

sometimes: ADV TC PART

'every now and then/ sometimes' 
As example (9) illustrates, this particular particle is shortened not only when attached to full morphemes such as pronouns (1-2SG and 1-2PL personal or demonstrative ones), common nouns (both animate and inanimate ones), adverbs etc., but also when attached to other particles (see ex. 10.) or endings in conjugated forms of verbs and adjectives (see section 2.2).

Ex. 10.

a)

$$
\begin{aligned}
& \text { 친구 }+ \text {-에 게서 }+ \text {-는 } \rightarrow \text { 친구에 게서는 } \rightarrow \text { 친구에 게선 } \\
& \quad \text { chingu -egeseo -neun chinguegeseoneun chinguegeseon } \\
& \text { friend:NABLPARTTCPART } \\
& \text { 'from the friend' }
\end{aligned}
$$$$
\text { b) 여동생 + -한테서 }+ \text {-는 } \rightarrow \text { 여동생한테서는 }
$$$$
\text { yeodongsaeng -hanteseo -neun yeodongsaenghanteseoneun }
$$$$
\text { younger sister: } \mathrm{N} \text { ABLPART TCPART }
$$$$
\rightarrow \text { 여동생한테선 'from the younger sister' }
$$

yeodongsaenghanteseon

Ex. 11. 집 뒤엔 공원이 있어. 'Behind the house (there) is a park.' (informal style) jip dwien gongwoni isseo

As mentioned above, it appears that the process of abbreviation of particles although common, applies mainly to the most frequently used ones. However it may be a surprise that there are very few examples of shortened forms with nominal case particles and that conjunction particles meaning 'and, along with' etc. such as -wa/gwa, - (i) rang, -hago (-와/과, - (이) 랑, -하고) as well as a large number of so-called 'special' particles such as - do (-도) meaning 'also, too', -man (-만) meaning 'only', -kkaji (-까지) meaning 'till (some time), to (some place) ', -jocha (-조차) meaning 'even', -cheoreom (-처럼) meaning 'as/ like (somebody/ something) ' are never shortened.

The reason could be their specific meaning, which in case of shortened forms might be lost and thus lead to confusion as to the exact meaning of a phrase e.g. if - man would be shortened to $-n$ as it is in already discussed neun. Nonetheless apart from the meaning conveyed by those auxiliary particles, their morphological structure could also play an important role here. None of the above mentioned cases, conjunction or 'special' particles have the same 
syllable structure as -neun (-는) or - reul (-를) does - namely CVC in vertical orientation.

Furthermore apart from contraction of particles there are also cases of particle reduction, which can be treated as clippings, although Bauer (1983: 233-4) and others refer to clipping only in the context of word formation and not in the context of declension or conjugation. They do mention however, the change of stylistic level, which can also be observed in Korean on the basis of given examples.

Although among particle clippings there are both back clippings (see ex. 12) and fore clippings (see ex. 14), far fewer examples of fore clippings can be found.

Ex. 12.

a) 언니 + -에게서 $\rightarrow$ 언니에 게서 $\rightarrow$ 언니에게 'from an older sister'
$\begin{gathered}\text { eonni } \\ \text { older sister:N ABLPART }\end{gathered}$

b) 남동생 + -한테서 $\rightarrow$ 남동생한테서 $\rightarrow$ 남동생한테 namdongsaeng -hanteseo namdongsaenghanteseo namdongsaenghante younger brother: NABLPART 'from a younger brother'

Ex. 13. 남자친구에 게 선물을 받았어요. 'I got a present from (my/ a) boyfriend.' namjachinguege seonmureul badasseoyo

As exemplified in (12) particles -egeseo (-에 게서) and -hanteseo (한테서) meaning 'from' have their last syllable clipped. Both of those clipped forms are commonly used with verbs such as 'to get' - batda (받다), 'to obtain' - eotda (얻다), 'to learn' - baeuda (배우다) etc.

Ex. 14.

a) 여기 + -에서 $\rightarrow$ 여기에서 $\rightarrow$ 여기서 'here/ from here' yeogi -eseo yeogieseo yeogiseo

here:DEMP LOC/ABLPART

b) 서울 + -에서 $\rightarrow$ 서울에서 $\rightarrow$ 서울서 'in Seoul/from Seoul' Seoul - eseo Seouleseo Seoulseo

here: DEMP LOC/ABLPART 
Among fore-clippings of particles there are e. g. - eseo shortened to seo and ida reduced to -da. - eseo (-에서) meaning either 'from' (a place) or 'in' (while talking about the action, which takes place in a particular place) can be clipped while being attached to both pronouns and nouns (proper names as shown in the above ex. 14b).

If we treat ida (이다) as the predicative case particle (Kor. 서술격조사, seosulgyeokjosa), as some Korean linguists do, we can observe that $i$ (이-) disappears when the preceding noun or pronoun ends with a vowel. Nevertheless it takes place only while talking about the present, which means that e. g. talking about the past $i$ will not be reduced.

\subsection{A conjugated word form with a particle}

Since -neun (-는) - an auxiliary particle used to mark topic-contrast in the sentence is shortened while being attached to nouns and pronouns (as exemplified in the above ex. 9) or another particle (as shown in the above ex. 10) we can easily presume and confirm this presumption that it will also tend to be abbreviated when added to various grammatical endings. As the following examples show particle -neun can co-create grammatical endings and give them an additional meaning of emphasis or stress. However, if the speaker does not want to emphasize anything - neun is simply not used.

Ex. 15.

a) AST/VST (c) +-으니까는 $\rightarrow$-으니깐 'since/ because of ADJ/V' -eunikkaneun -eunikkan

b) AST/VST (c) +-을 때는 $\rightarrow$-을 땐 'when/ while/ during ADJ/V'

c) AST/VST (c/v)+-기 때문에는 $\rightarrow$-기 때문엔 
-gittaemuneneun -gittaemunen

'on account of/ because of/ owning to $\mathrm{ADJ} / \mathrm{V}$ '

Ex. 16. 그녀는 젊었을 땐 상당한 미인이었어요. geunyeoneun jeolmeosseul ttaen sangdanghan miinieosseoyo 'She was quite a beauty when she was young.'

\section{Endings}

Among extremely numerous short forms of endings in Korean we can discover two ways according to which they are being formed - that is, as it was in the case of particles, contraction and clipping. The first one takes place when two vowels meet - one of them comes from a verb or an adjective stem and the other o ne from an ending. The process is called vowel shortening (모음축약; moeumchugyak) in Korean. Graphically shortened vowels are pronounced as a diphthong, however, only vowels which can create a diphthong are actually shortened. It applies, as 김정숙 (2005: 495) explains, only to the three below cases - when the last vowel in a stem is $-i,-u$ or $-o$ ( $\mid, 丁, \perp)$.

Generally when a monosyllabic stem ends with one of those three vowels, the shortening is not compulsory, however when a disyllabic or longer stem ends with an $i(\mid)$, in other words, the longer the stem the more frequent usage of short forms. Pida (피다) 'to bloom/ blossom', ppajida (빠지다) meaning 'fall/ get into, sink down into', juda (주다) meaning 'to give/ award/ provide' and boda (보다) meaning 'to see/ look' will serve as examples here.

Ex. 17.

a) 피- +-어서 $\rightarrow$ 피어서 $\rightarrow$ 펴서

pi- - еоseo pieoseo pyeoseo

bloom: VST because: END

‘because bloom/ blossom' (e. g. roses)

b) 빠지- + -어도 $\rightarrow$ 빠지어도 $\rightarrow$ 빠져도

ppaji- -eodo ppajieodo ppajeodo

fall into: VST even though: END 
'although/ even if/ even though (I/you/ they etc.) fall into' (e. g. love)

c) 주- + -어요 $\rightarrow$ 주어요 $\rightarrow$ 줘요 'I (you/ they etc.) give'

ju- -еоуо jueoyo jwoyo

give: VST PRESEND

d) 보- + -았어요 $\rightarrow$ 보았어요 $\rightarrow$ 봤어요 '(I/you/ they etc.) saw'

bo- -asseoyo boasseoyo bwasseoyo see: VST PSTEND

However, apart from the above-mentioned abbreviated forms there is also an example like -jiyo (-지요) used as a question tag, where the ending itself can take a shorter form, namely -jyo (-죠) despite morphological properties, in other words regardless of the auslaut of the preceding stem.

Ex. 18. AST/VST (c/v) -지요 $\rightarrow$-죠

a) 예쁘- $\quad+$-지요 $\rightarrow$ 예쁘지요 $\rightarrow$ 예쁘죠? 'Beautiful isn't it?'

уерреи- - jiуо уерреијіуо уерреијуо

be bautiful: AST question tag: END

b) 갔- + -지요 $\rightarrow$ 갔지요 $\rightarrow$ 갔죠?

gat- -jiyo gatjiyo gatjyo

go: VSTPST question tag: END

'You (he/ they etc.) went didn't you (he/they etc.) ?'

Furthermore, it is also worth mentioning the conjugation of the extremely numerous and thus extensively used, verbs and adjectives stems with ha- (하-). Words such as ilhada (일하다) 'to work', yeohaenghada (여 행하다) 'to travel' etc. when followed by a vowel ending can appear either in a long or reduced form. However, two neighboring vowels (one from $h a-$ stem and the other from an ending) are generally abbreviated, which mainly applies to spoken Korean, although short forms are used in an informal written language as well.

Ex. 19.

a) 일하- + -여요 $\rightarrow$ 일하여요 $\rightarrow$ 일해요 'I(you/ they etc.) work' ilha- - yeoyo ilhayeoyo ilhaeyo work: VST PRES: END 
b) 여행하- + -여서 $\rightarrow$ 여행하여서 $\rightarrow$ 여행해서

yeohaengha- $\quad$ yeoseo $\rightarrow$ yeohaenghayeoseo $\rightarrow$ yeohaenghaeseo

travel: VST because: END

'because I (you/ they etc.) travel'

c) 하락하- + -였어요 $\rightarrow$ 하락하였어요 $\rightarrow$ 하락했어요

haraka- -yeosseoyo harakayeosseoyo harakaesseoyo

decrease/ decline: VST PSTEND

' (It) decreased/ dropped'

d) 싱싱하- + -였지만 $\rightarrow$ 싱싱하였지만 $\rightarrow$ 싱싱했지만

singsingha- -yeotjiman singsinghayeotjiman singsinghaetjiman

be fresh: AST but though: PST END

'though fresh'

Vowel reduction also applies to frequently used expressions with the above-mentioned $\mathrm{ha}$ - (하-) stems, as exemplified in the below 20.

Ex. 20.

a) N(v) -를 위하여 $\rightarrow$-를 위해 'for/ for the sake of/ for the benefit of N' -reul wihayeo -reul wihae

b) N(c)-으로 인하여 $\rightarrow$-으로 인해 'because of/ on account of/ due to N' -euro inhayeo -euro inhae

c) $\mathrm{N}(\mathrm{c} / \mathrm{v})$-에 비하여 $\rightarrow$-에 비해 'in comparison with/ to N' -e bihayeo -e bihae

d) $\mathrm{N}(\mathrm{c} / \mathrm{v})$-에 관하여 $\rightarrow$-에 관해 'about/ on/ regarding/ concerning N' -e gwanhayeo -e gwanhae

e) N(c/v) -에 의하여 $\rightarrow$-에 의해 'on the ground of/ according to N' -e vihayeo -e uihae

Apart from the above-discussed vowel shortening there is also fairly common ending reduction mainly through back clipping. Some examples are provided below. 
Ex. 21.
a) VST (v/c)-기 위해서 $\rightarrow$-기 위해
'in order to V'
-giwihaeseo -giwihae
b) VST (v/c) -느라고 $\rightarrow$-느라 -neurago -neura
'because of/ due to $\mathrm{V}$; with the intention of doing $\mathrm{V}$,
c) AVS/VST (c) -으니까 $\rightarrow$-으니 'since/ because ADJ/V -eunikka -euni
d) $\quad \mathrm{N}(\mathrm{c})$ 이라서 $\rightarrow$-이라 'since/ because it is [it was] N' iraseo -ira

As example (21) illustrates the clipped part concerns the last syllable and it does not exceed its boundary.

\section{Grammatical Constructions}

In addition to particles and endings discussed above, there are numerous grammatical constructions that are commonly abbreviated as well. Some of these forms have more than one abbreviated form - namely the longer and the shorter one. They are especially characteristic to reported or indirect speech as shown in the below example.

Ex. 22.

a) Attributive form (affirmative)

$$
\begin{aligned}
\mathrm{VST}(\mathrm{c}) \text {-는다고 } \text { 하는 } \rightarrow \text {-는다는 } \rightarrow \text {-는단 } \\
\text {-neundago haneun } \rightarrow \text {-neundaneun } \rightarrow \text {-neundan }
\end{aligned}
$$

b) Attributive form (interrogative)

$$
\begin{aligned}
& \mathrm{VST}(\mathrm{v} / \mathrm{c}) \text {-느냐고 하는 } \rightarrow \text {-느냐는 } \rightarrow \text {-느난 } \\
& \text {-neunyago haneun -neunyaneun -neunyan }
\end{aligned}
$$




$$
\begin{gathered}
\text { AST (c)-으냐고 하는 } \rightarrow \text {-으냐는 } \rightarrow \text {-으냔 } \\
\text {-eunyago haneun -eunyaneun -eunyan }
\end{gathered}
$$

c) Attributive form (propositive)

$$
\begin{array}{ccc}
\mathrm{VST}(\mathrm{v} / \mathrm{c}) \text {-자고 하는 } & \rightarrow \text {-자는 } & \rightarrow \text {-잔 } \\
\text {-jago haneun } & \text {-janeun } & \text {-jan }
\end{array}
$$

d) Attributive form (imperative)

$$
\begin{array}{ccc}
\text { VST (c) -라고 하는 } & \rightarrow \text { - 라는 } & \rightarrow \text {-란 } \\
\text {-rago haneun } & \text {-raneun } & \text {-ran }
\end{array}
$$

Apart from the above-mentioned abbreviation of attributive forms of indirect speech there are also examples where after the contraction of a constituent of the reported speech construction - namely particle - go (-고) and $h a$ (하-) back clipping also takes place. Here the clipped part can be either exactly one syllable long (see ex. 23) or can exceed this boundary by the reduction of $n$ (-ᄂ) in the penultimate syllable of the conjugated form (cf. ex. 24). Reduction of sentences with indirect speech applies to all types of sentences and constructions, below however there are only few examples given.

Ex. 23.
a) VST (v)-ㄴ다고 하니까 $\rightarrow$ - ㄴ다고 하니 $\rightarrow$ - ㄴ다니 -n dago hanikka -ndago hani $\quad$-ndani 'since (somebody) said that...'

b) $\operatorname{VST}(\mathrm{c} / \mathrm{v})$-느냐고 하니까 $\rightarrow$-느냐고 하니 $\rightarrow$-느냐니 -neunyago hanikka -neunyago hani -neunyani 'since (somebody) asked whether V'

c) $\operatorname{VST}(\mathrm{c} / \mathrm{v})$-자고 하니까 $\rightarrow$-자고 하니 $\rightarrow$-자니 -jagohanikka -jagohani -jani 'since (somebody) proposed/suggested to $\mathrm{V}$ '

d) VST(v)-라고 하니까 $\rightarrow$-라고 하니 $\rightarrow$-라니 -ragohanikka -ragohani -rani 'since (somebody) told to/ ordered to V' 
Ex. 24.

a) VST(v)-ㄴ다고 하면서 $\rightarrow$-ㄴ다면서 $\rightarrow$-ㄴ다며

-n dago hamyeonseo -n damyeonseo -n damyeo

'doing (something) while saying V'

b) VST (c/v)-느냐고 하면서 $\rightarrow$-느냐면서 $\rightarrow$-느냐며 -neunyago hamyeonseo -neunyamyeonseo -neunyamyeo 'doing something while asking if/ whether V'

c) $\operatorname{VST}(\mathrm{c} / \mathrm{v})$-자고 하면서 $\rightarrow$-자면서 $\rightarrow \quad$-자며 -jago hamyeonseo -jamyeonseo -jamyeo 'doing (something) while proposing V'

d) VST (c)-라고 하면서 $\rightarrow$-라면서 $\rightarrow$-라며 -rago hamyeonseo -ramyeonseo -ramyeo 'doing (something) while ordering V'

In some cases, as illustrated in the below (25), abbreviation and clipping enable morpheme reduction even up to 50\%. Examples c) $\sim$ ) also show that grammatical and lexical abbreviation can take place at the same time.

Ex. 25.

a) 그렇게 하지 말라고 하니까 $\rightarrow$ 그렇치 말라니 geureoke haji mallago hanikka geureotchi mallani 'Because (I/ they etc.) tell (you) not to do so.'

b) 그렇게 하려면 $\rightarrow$ 그러려면 'if intending to do so' geureoke haryeomyeon geureoryeomyeon

c) 지금 출발한다고 합니다. $\rightarrow$ 짐 출발한답니다. jigeum chulbalhandago hamnida jim chulbalhandamnida ' (Somebody) said that (he/ she) will depart now.'

d) 우리 언니는 같이 먹자고 해요. $\rightarrow$ 울 언닌 같이 먹재요. uri eonnineun gachi meokjago haeyo ul eonnin gachi meokjaeyo 'Older sister suggests/ suggested eating (together).'

Moreover it is no surprise that if a particular word e. g. a synsemantic 
noun (Kor. 의존명사, uijonmyeongsa) such as geot (것) meaning 'a thing', a verb gajida (가지다) meaning 'to have, to possess, to hold' or an adjective anihada (아니하다) meaning 'to be not/ to do not', has its shortened form, its form is also abbreviated when used as a part of a grammatical construction, which can be exemplified with the below (26) (28).

Ex. 26. 것 $(\mathrm{geot}) \rightarrow$ 거 $(\mathrm{geo})$ 'a thing'

a) AST/VST-(으) 르 것이다 $\rightarrow$-(으) 르 거다 'will ADJ/V' - (eu) l geosida - (eu) l geoda

b) AST/VST - (으) 르 것입니다 $\rightarrow$ - (으) 르 겁니다 - (eu) l geosimnida - (eu) l geomnida 'will ADJ/V' (formal style)

c) AST/VST -았을 것입니다 $\rightarrow$-았을 겁니다 -asseul geosimnida -asseul geomnida 'would ADJ/V' (formal style)

Ex. 27. 가지다 (gajida) $\rightarrow$ 갖다 (gatda) 'to have/ to possess/ to hold'

a) $\mathrm{N}(\mathrm{c})$-을 가지고 $\rightarrow$-을 갖고 'by/ by means of/ with N' -eul gajigo -eul gatgo

b) AST/VST-아/어 가지고 $\rightarrow$ _아/어 갖고 'because of ADV/V', -a/eo gajigo -a/eo gatgo 'having done/ after doing'

Ex. 28. 아니하다 (anihada) $\rightarrow$ 않다 (anta) 'to be not/ to do not'

a) AST/VST-지 않다 (-ji anta) 'to be not ADV/ to do not V'

Anta (않다) is used as an auxiliary word expressing negation. It becomes either an auxiliary verb or an auxiliary adjective, depending on a word class to which the preceding word belongs. Anta is used with an auxiliary ending -ji (-지), however when it is attached to a $h a$ - (하-) stem it can be abbreviated, which is also worth mentioning here, since it is a fairly common thing. Although its function stays the same, the meaning however, changes into less formal one. 
The resultant forms (coming from the negation of $h a$ - stems with the above-mentioned -ji anta) can appear either as -chi anta (-치 않다) or even shorter -chanta (-찮다), or as -ji anta (-지 않다) and shorter -janta (-잖다). Everything depends, as Professor 김지형 explains, on morphological features of the syllable preceding $h a$ - (하-). If that syllable ends with a voiced consonant (Kor. 유성자음, yuseongjaeum) such as 'ㄹ, ᄂ, ㅁ, O' or a vowel, vowel $a$ in $h a$-is omitted. However, if it ends with an unvoiced consonant (Kor. 무성자음, museongjaeum), to which belongs every consonant except for 'ㄹ, ᄂ, ㅁ, O', ha- is omitted.

Ex. 29.
a) 성실하- + -지 않다 $\rightarrow$ 성실하지 않다 $\rightarrow$ 성실치 않다 seongsilha- $-j i$ anta seongsilhaji anta seongsilchi anta be sincere: AST AUXEND AUXADJ: NEG
$\rightarrow$ 성실찮다 'be not sincere' seongsilchanta

b) 심심하- + -지 않다 $\rightarrow$ 심심하지 않다 $\rightarrow$ 심심치 않다 simsimha- $-j i$ anta simsimhaji anta simsimchi anta be bored: AST AUXEND AUXADJ:NEG

$\rightarrow$ 심심찮다 'be not bored' simsimchanta

c) 피곤하- + -지 않다 $\rightarrow$ 피곤하지 않다 $\rightarrow$ 피곤치 않다 pigonha- $-j i$ anta pigonhaji anta pigonchianta be tired: AST AUXEND AUXADJ:NEG

$\rightarrow$ 피곤찮다 'be not tired' pigonchanta

The omission of ' $a$ ' leaves ' $h$ ' in the immediate vicinity of ' $j$ ' ( ᄌ ) seongsil $h+-j i$ anta (성실흐 +-지 않다). According to pronunciation rules in Korean $h$ (하) and $j$ (ㅈ) are pronounced as ch (ㅊ), as it is in 'Jochiyo?' (좋지요?) meaning ' (It's) good isn't it?' pronounced as jochiyo [조치요]. Here, however, this particular rule is also reflected in a written form. 
Ex. 30.
a) 깨끗하- + -지 않다 $\rightarrow$ 깨끗하지 않다 $\rightarrow$ 깨끗지 않다 kkaekkeuta- -ji anta kkaekkeutajianta kkaekkeutjianta be clean: AST AUXEND AUXADJ:NEG

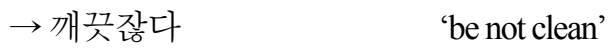 kkaekkeutjanta

b) 넉넉하- + -지 않다 $\rightarrow$ 넉넉하지 않다 $\rightarrow$ 넉넉지 않다 neongneoka- -ji anta neongneokajianta neongneokjianta be enough: AST AUXEND AUXADJ:NEG

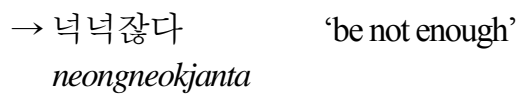

c) 섭섭하- + -지 않다 $\rightarrow$ 섭섭하지 않다 $\rightarrow$ 섭섭지 않다 seopseopa- -ji anta seopseopajianta seopseopji anta be disappointed: ASTAUX END AUXADJ: NEG $\rightarrow$ 섭섭잖다
seopseopjanta

Most linguists investigate clipping only in the context of word formation. However this phenomenon, as this article attempted to show, can also be observed in Korean in the field of conjugation. That is why the author suggests to broaden the meaning of clipping info this field too.

\section{Concluding Remarks}

The usage of various kinds of abbreviations in the era, where collecting the data is all-pervasive, where the significance of efficient communication is constantly 
growing and the acceleration of the pace of everyday life is so prominent it seems that using short forms of words and phrases is inevitable despite the fact that it can also cause confusion when overused.

Since abbreviation in Korean can be applied to both lexical and grammatical material abbreviated forms consequently can also be divided into lexical and grammatical ones. Among the abbreviations of the second type, which were the subject of this article, shortening of particles, endings and grammatical constructions are found. This process, fairly common especially in spoken Korean, results not only in the quantitative changes observable through the reduction of the number of syllables but also through their restructuring.

Interestingly enough, despite wide usage this process concerns only relatively narrow group or particles and endings. It both cases, however, it can be done in two ways - namely through contraction and clipping.

Endings are abbreviated in order to avoid a string of two vowels and regardless of a word class of a stem - an adjective or a verb. Nevertheless it involves only vowels which able to form a diphthong such as: $i, o$ and $u$. Apart from this so-called 'vowel shortening' abbreviation of extremely numerous in Korean $h a$ - stems followed by a vowel ending is also noteworthy. The abovementioned curtailed forms of $h a$ - are also very commonly used in various grammatical construction, especially those where indirect speech is involved.

As far as particles are concerned, the most frequently shortened one is an auxiliary particle -neun meaning 'the', which can be shortened when attached either to various word classes such as nouns or pronouns, to another particle or even conjugation endings. This however concerns only words, particles and endings, which end with a vowel.

Only a few of the case particles and interestingly enough none of the conjunction particles are actually shortened. Nominal, accusative, genitive and locative case particles can serve as an example here. Nevertheless the situation of the first one and the last two is considerably different since their abbreviation not only strongly depends on morphological structure of a word (as it is in the case of -neun) but also often on its semantic properties too. And so, nominal case particle is shortened when attached to demonstrative pronouns; both genitive and locative case particles when attached to 1-2SG personal pronouns with the exception of the consonant-ended dangsin. The accusative case however apart from pronouns can be abbreviated when attached to nouns as well.

The answer to the question why none of the conjunction particles and only few of the case and 'special' particles are shortened is that, it could obscure their meaning and thus the tendency to maintain the comprehensibility of the 
message, which could be lost if particle was shortened. This would happen if e.g. one of the auxiliary particles - man (-만) meaning 'only' would be reduced to $-n$ as it happens with the above-mentioned particle -neun.

Among particles and endings in question there are also clipped forms. Particles can be formed through back clipping, however there are a few examples of fore clipping as well. Among endings though there are basically back clippings and they usually, as it is in the case of particles, involve one syllable only. Nevertheless there are also endings, which have more than one syllable reduced.

There are also two interesting phenomena concerning abbreviation. The first one is that the lexical abbreviation is also reflected in the grammatical one, since lexical abbreviations e.g. of a noun or a verb are used in grammatical constructions. The second one confirms the context-based usage of abbreviated forms - namely that the abbreviation even of the grammatical type produces homonyms. The short forms such as nae (내) meaning 'mine', naneun (나는) meaning ' $\mathrm{I} / \mathrm{me}$ ' and nada (나다) meaning 'it's me' beyond the context can also convey the meaning of 'smoke, fume, a smell' or 'an odor'; 'a column or a section in a newspaper, a rebellion' or 'an orchid' and 'come into being (existence), grow, happen, come across' respectively.

Grammatical abbreviation usually accompanies the lexical one. Nevertheless, for the sake of brevity, only certain selected issues concerning Korean abbreviology in the grammatical aspect were analyzed here. The subject of abbreviation in Korean though certainly deserves further discussion and in-depth analysis. The intention of the author is to inquire more comprehensively in the domain of abbreviation in the Korean language in the future.

\section{BIBLIOGRAPHY}

Bauer, Laurie. 1983. English Word-formation. Cambridge: Cambridge University Press.

Bauer, Laurie. 2001. Morphological Productivity. Cambridge: Cambridge University Press.

Buttler, Danuta 1987. Kilka uwag o konstrukcjach skrótowych w ję- 
zyku polskim. Poradnik Językowy 8 (447): 641-45.

Cambrigde Online

Dictionary.

http://dictionary.cambridge.org/grammar/british-

grammar/word-formation (accessed August 15, 2014).

Cannon, Garland. 2011. Abbreviations and Acronyms in English

Word-Formation. American Speech 64: 2: 99-127.

Choo Miho and Kwak Hye-Young. 2008. Using Korean, A Guide to Contemporary Usage. Cambridge: Cambrigde University Press.

Gajos, Mieczysław. 2000. Formy skrócone rzeczowników francuskich oznaczających osoby. Studia Romanica Posnaniensia 25/26: 89-96.

Gołąb, Zbigniew, Heinz Adam and Polański Kazimierz. 1968. Słownik Terminologii Językoznawczej. PWN.

Hamans, Camiel. 2008. Why clipped words should be accepted as noun. Lingua Posnaniensis 50: 95-109.

Kang, Eungyeong. 2013. An Optimality-theoretic analysis of lexical blends in Korean. 언어학 연구 28 (4): 653-72.

Ko, Kil Soo. 2008. Korean Postpositions as Weak Syntactic Heads. In Proceedings of the 15th International Conference on HeadDriven Phrase Structure Grammar, National Institute of Information and Communications Technology, ed. Stefan Müller, 131-51. Stanford, CA: CSLI Publications.

Lee, Ikseop and Ramsey, Samuel Robert. 2000. The Korean Language. New York: State University of New York Press.

Lee, Ki-Moon and Ramsey, Samuel Robert. 2011. A History of Korean Language. Cambridge: Cambridge University Press.

Maciejewska-Wójcik, Anna and Smoleń-Wawrzusiszyn, Magdalena. 2013. O potrzebie leksykonu skróceń historycznych. Zamysł I dylematy badawcze. Prace Filologiczne LXICV (1): 201-10.

Marchand, Hans. 1966. The Categories and Types of Present-day English Word-formation, A Synchronic-Diachronic Approach. Alabama Linguistic and Philological Series \#13. Tuscaloosa: University of Alabama Press.

Martin, Elmo Samuel. 2002. A Reference Grammar of Korean. A Complete Guide to the Grammar and History of the Korean Language. Singapore: Tuttle Publishing. 
Matthews, Peter Hugoe. 1974. Morphology. An Introduction to the Theory of Word-structure. Cambridge: Cambridge University Press.

Młodyński, Józef. 1974. Stan badań nad skrótowcami. Poradnik Językowy 8: 407-16.

Młodyński, Józef. 1975. Klasyfikacja skrótów polskich. Poradnik Językowy 10: 546-53.

Müldner-Nieckowski, Piotr. 2007. Wielki słownik skrótów i skrótowców. Wrocław: Wyd. EUROPA.

Plag, Ingo. 2002. Word-formation in English. Cambridge Textbooks in Linguistics. Cambridge: Cambridge University Press. (Draft version of $27^{\text {th }}$ September 2002).

Podracki, Jerzy. 1999. Słownik skrótów i skrótowców. Warszawa: Wyd. Naukowe PWN.

Polański, Kazimierz (ed). 1999. Encyklopednia językoznawstwa ogólnego. Wrocław: Ossolineum.

Puzynina, Janina. 1976. Skróty językowe - charakterystyczna struktura XX w. In Z problemów współczesnych języków i literatur słowiańskich. 82, 85. Warszawa: Wyd. Uniwersytetu Warszawskiego.

Rhee, Seongha. 2006. Stratified Complex Postpositional System in Korean: A Contact Linguistics Perspective. 담화와 인지 13 (2): $159-84$.

Sobczykowa, Joanna. 1983. Skróty językowe w opinii społecznej w świetle wypowiedzi na łamach Poradnika Językowego. Socjolingwistyka 5: 77 - 99.

Sohn, Ho-Min. 1999. The Korean Language. Cambridge: Cambridge University Press.

Song, Jea Jung. 2005. The Korean Language, Structure, use and context. London and New York: Routledge Taylor \& Francis Group.

Stockwell, Robert and Minkova, Donka. 2001. English Words, History and Structure. Cambridge: Cambridge University Press.

Szadyko, Stanisław. 1997. Akronimy. Zeszyty Naukowe SGH 3: 11630 .

강연임. 2005. 한국어 담화와 생략. 서울: 이회문하사.

김원경. 2009. 한국어의 격. 서울: 박문사.

김정은. 2000. 국어 단어형성법 연구. 서울: 박이정. 
김지형의 국어마당 School of Korean Kyung Hee Cyber University. http://kugmun.com/?document_srl=3661 \&mid= bbs7\&category=3488 (accessed February 11, 2015).

김창섭. 1996. 국어의 단어형성과 단어구조 연구. 국어학총서 21. 서울: 태학사.

나찬연. 2007. 국어문법의 이해. 서울: 제이앤씨.

남기심, 고영근. 2006. 표준국어문법론. 서울: 탑출판사.

려춘연. 1999. 준말의 발생과 발전. 중국조선어문 104: 34-7. 길림성민족사무위원회.

박홍길. 1986. 홀소리 줄임에 관한 연구 - 주말 추게와 관하여-. 새얼어문논집 2: 87-135.

송홍규. 2011. 준말에서의 어미 결함 제약에 대하여. 한어문교육 24: 554-579.

시정곤. 1994. 국어의 단어형성 원리. 국학자료원. 언어학연구 12. 이지양. 1993. 국어의 융합현상과 융합형식 (國語의 融合現象과 融合形式), 서울대학교 대학원, 박사학위논문.

임동훈. 2005. 한국어의 조사. 외국어로서의 한국어학. 서울: 한국방송통신대학교출판부.

임지룡, 이은교, 김총록, 송창선, 황미향. 2005. 학교문법과 문법교육. 서울: 도서출판 박이정.

정희창. 2006. 준말의 단어 형성문제. 반교어문학회 21: 108-18. 최규일. 2009. 한국어 어휘형성론. 제주: 제주대학교 출판부. 최현배. 1994. 우리말본. 서울: 정음문화사. 